\title{
Knowledge-Based Economy
}

\author{
Ahmed S. Alomari, Ph.D., MBA, PMP® \\ King Faisal Specialist Hospital \& Research Center Riyadh, \\ Saudi Arabia \\ alomari@kfshrc.edu.sa
}




\section{Introduction}

Saudi Arabia is an oil-reliant nation as a large percentage of its GDP comes from oil resources. Oil dependency leaves a county at the mercy of the international crude market, and a decrease in the price of crude can seriously destabilize the economy of such nations. An example is the case of Venezuela whose dependence on oil caused a national disaster (McCarthy, 2017). As such, the nation's exports, GDP, and government revenue are primarily dependent on oil revenue, and the recent decrease in the oil prices has decreased Venezuela's national revenue resulting in economic collapse as well as inflation. A shift from a resource based economy to a knowledge based economy will help Saudi Arabia become less reliant on its oil revenues for its economic stability and growth (Nurunnabi, 2017).

\section{Knowledge-Based Economy}

Knowledge has been long considered an essential factor of production alongside labor, capital, and resources. However, due to the limited nature of resources and the abundance of knowledge as a resource as well as it's potential to improve productivity as well as economic growth more emphasis is now placed on the importance of knowledge. A knowledge-based economy can be defined as one that relies more on its intellectual capabilities for its economic growth and long-term stability rather than natural resources or physical inputs. As such, the knowledge-intensive activities within the economy result in a rapid increase in technical and scientific advances that gives the nation a competitive advantage over other countries. In the case of Saudi Arabia, since the country discovered oil in 1938 its economy and standard of living have grown (Nurunnabi, 2017). As a result, the nation has become a resource-based nation due to its dependency on oil. However, the government has realized that oil dependency is not sustainable especially for the long-term economic growth of the nation. A more sustainable option for the nation will be for it to shift from a resource-based economy to a knowledge-based economy.

Knowledge has become extremely important to nations as knowledge is now recognized as a factor responsible for the increase in productivity, the standard of living and economic growth 
within an economy. Knowledge development in a nation requires close interaction between the government, private sector, regulatory frameworks or policies, and the public. The government plays an important role in Knowledge-based economies as they are responsible for providing a regulatory framework. Organizations and companies spend a lot of funds to create intellectual goods and services as well as new innovations and technologies. To protect these new innovations and technologies and to ensure that its creators receive compensation for their work governments must establish mechanisms such as intellectual property rights as part of its regulatory framework to protect firms in its IT industry (Fang, Lerner, \& Wu, 2017).

The knowledge economy is viewed as the latest stage of development in global economic restructuring. Global economies are viewed to have first begun as agricultural economies which then developed to industrial or manufacturing economies then to post-industrial economies or mass production economies. The knowledge economy is viewed as the latest stage in this evolution as innovation, and highly skilled human capital are the main drivers of this type of economy (Ejdys, Ustinovičius, \& Stankevičienè, 2015).

\section{The Main Features or Attributes of a Knowledge-Based Economy}

A feature of a knowledge-based economy is the investment in the development of the human capital of a nation. Studies have shown that improving human capital increases productivity as well as the innovation capacity of employees (Nurunnabi, 2017). A way that governments and organizations can aid in the development of human capital is to provide initiatives such as training programs, mentorship, and workshops aimed at improving the knowledge and skill levels in workers. Also, this also allows workers the ability to shift from one career to another while also making them more resilient to changes in the workplace. An example in the investment in human capital is the increase in government expenditure on research and development. Improving basic research in universities through improved government funding can greatly improve the level of new innovations and technology produced by a nation setting it on the path to become a knowledge-based economy. Saudi Arabia spends a small percentage of its GDP on research and development, and this limits the creation of new innovations and technology. 
Another important feature of a knowledge-based economy is the investment in the nation's education system at all levels. Education is important to an economy as it is the center for knowledge and the quality of human capital largely depends on the quality of the education system in a nation. The improving a country's education systems such as improving factors which include teacher to student ratio can greatly improve the quality of education pupils receive.

Access to funding for startup companies is another important aspect of knowledge-based economies. Technological companies are an important part of knowledge-based economies, and new technology companies require non-financial support and as well as funding. An example is Silicone Valley in the United States which receives both domestic and foreign funding from countries such as Saudi Arabia. As a result, through this funding, many large technology companies and discoveries have emerged. Economic stability is another feature of a knowledgebased economy, and this is due to economic diversity as there are many different industries that contribute to the nations GDP (Hadad, 2017). In contrast, resource-based economies depend on a single or a few commodities that leave the nation's economy exposed internal and external threats such as the rise in commodity prices. Another reason why knowledge-based economy is usually stable is because firms have access to different government support systems that allow them to grow and expand. An attribute of knowledge-based economy is the increase in the number of high paying high skill jobs, especially in the IT industry. A common trend that has been noticed around the world is the decrease in the number of low skill low wage jobs as more companies are using technology to replace these types of workers. However, the need for highly skilled workers in both the private and public sectors has greatly increased as knowledge has been directly linked with the increase in productivity in both sectors.

Enough infrastructure is another important aspect of a knowledge-based economy. Due to globalization communications technology has become an important aspect of knowledge-based economies and ensuring that citizens have access to communications tools such as the internet and fixed or mobile telephones is important for governments. An example is the case of Saudi Arabia where between 2010 and 2015 access to the internet increased by close to 70\%, and this was made 
possible by government expenditure on infrastructure and growth in the telecommunications industry (Nurunnabi, 2017). The final feature of knowledge-based economy is a robust financial system which allows for the easy movement of a financial resource such as investments within the economy. Also, the financial system should also meet the capital needs of startups as well as structure development projects aimed at attracting new investors.

\section{The Reasons Countries Want to Transfer to a Knowledge-Based Economy Including Saudi Arabia}

Countries need to transfer to knowledge-based economies especially Saudi Arabia which is an oil-dependent economy as this is a more sustainable economic model in the long run. One of the major advantages of a knowledge-based economy is that it reduces the problem of inequality in a nation as workers are not restricted to low wages, but through human capital, development can receive higher wages due to their skills (Hadad, 2017). A knowledge-based economy also offers many opportunities for sustainable economic growth as the improvement in innovations and technology as a result of better skilled human capital will allow for the growth in high-tech segments such as manufacturing electronics, software engineering, services such as banking, finance, and telecommunications.

Another reason why Saudi Arabia would want to be a knowledge-based economy is because the world's economy is increasingly becoming integrated through globalization. As such, knowledge has become an important part of this global economy as it aids in the flow of goods, services, and information between nations. Also, economies around the world must increase their flexibility, and their adaptability as market conditions around the world are constantly changing. An example is an increase in the demand for clean energy which coincides with a decrease in the demand for fossil fuels. As such, through the diversification which a knowledge-based economy offers a nation can easily shift to the development of clean energy technology instead of relying on its natural resources like Saudi Arabia. Saudi Arabia would want to become a knowledgebased economy as it would solve a fundamental problem that the country is facing which is unemployment. A knowledge-based economy would increase the size of both the private and 
public sector allowing graduates to find career opportunities in different fields. Saudi Arabia would want to become a knowledge-based economy because this would increase its innovations output (Nurunnabi, 2017). The global market for innovations which is regulated through mechanisms such as Intellectual Property Rights (IPR) is constantly increasing as the demand for intellectual goods such as computer software increases. However, Saudi Arabia has a low innovation output which shifting to a knowledge-based economy will allow the nation to expand into this market.

Another important reason why Saudi Arabia would want to become a knowledge-based economy is due to its annual growth in its total population. In 1960 the total population was 4.09 million, and by 2015 it had grown to over 31 million.

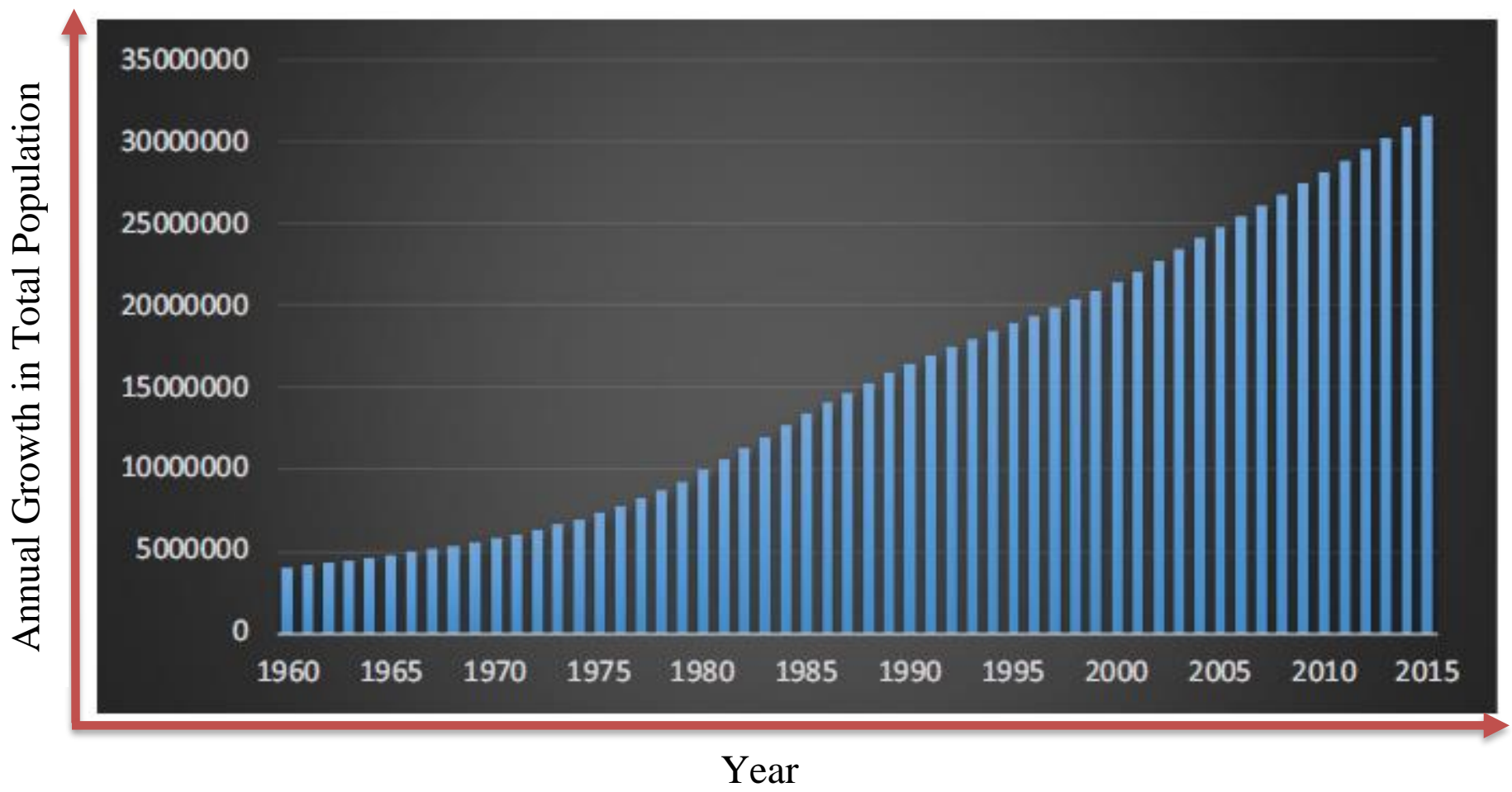

Figure 1: Saudi Arabia Population (Nurunnabi, 2017)

A growing population has several needs including growth in government expenditure to offer enough services to this growing population and an increase in employment opportunities to ensure that this growing population has enough income opportunities. As such, a major aspect of 
a knowledge-based economy is strengthening the link between tertiary education and the labor market thus improving the transition from school-to-work. Consequentially, this strengthens the job market allowing it to absorb any increases in population while also providing the government with revenue in the form of income-taxes.

The high cost of innovation is another reason why nations such as Saudi Arabia would like to become knowledge-based economies so that they can produce their own technology instead of depending on other nations. Innovation is fast becoming an integral part of economic growth as almost all industries including primary and secondary industries such as agriculture and manufacturing are becoming more reliant on new innovations and technologies to remain competitive, efficient, productive and profitable. An example of the high cost of new innovations and technologies in Saudi Arabia is a large amount of money the nation spends on new military technology which it acquires from nations such as the United States (Pan, Chang, \& Wolde-Rufael, 2015). However, if the nation were already a knowledge base economy, it would have easily created a military technology industry which would supply the Government with the latest military technology as well as exports to other countries that may require similar goods.

\section{The Ways Saudi Arabia Is Transforming and Planning to Transform into A Knowledge- Based Economy}

Saudi Arabia has realized the importance of shifting from a resource base economy to knowledge-based economy and has begun to plan and to transform in preparation for this shift. A major transformation witnessed in Saudi Arabia aimed at shifting the economy to a knowledgebased economy is the introduction of policies aimed at increasing research and development expenditure, human capital development and decreasing unemployment. Plans put in place to ensure the transformation of Saudi Arabia's economy to a knowledge-based economy are the Vision 2030 plan and the National Transformation Program 2020. The elements of the Vision 2030 plan Vision and the National Transformation Program 2020 which are aimed at transforming Saudi Arabia's economy into a knowledge-based economy is the decrease in oil exports as well as the increase in non-oil revenue. Consequentially, this will reduce the country's dependence on its oil 
(Nurunnabi, 2017). The creation or the building of an international complex for marine industries is not only direct investment in Saudi Arabia's knowledge-based industry, but it will also help to tackle the unemployment problem that the nation is currently facing. A large part of Vision 2030 plan and the National Transformation Program 2020 is diversifying the economy through the development of different sectors which support a shift to a knowledge-based economy such as health, infrastructure, entertainment, education, and tourism (Mitchell \& Alfuraih, 2018).

An important aspect of Vision 2030 which helps Saudi Arabia in its transformation into a knowledge-based economy is its provision for the funding of startups. Funding startups are essential to improving the level of technological entrepreneurship in the nation by offering access to financial. Also, the government can also aid in eliminating some of the challenges that limit the growth of startups through non-financial support such as providing work space or training. Despite the investment in startups, a major concern with Saudi Arabia's plan to transform from a resourcebased economy to a knowledge-based economy is the lack of investment in research and development. Saudi Arabia currently spends a small percentage of its GDP on research and development and this should increase to be in line with other G20 countries as this is an important aspect for the transition into a knowledge-based economy.

An important aspect of a knowledge-based economy is improving the partnership between the public and private sector. Saudi Arabia views the private sector as key to it archiving its Vision 2030 plan. As part of the Vision 2030 plan, the government expects the private sector to increase its contribution to GDP to $65 \%$ and one of the ways that this can be archived to increase investment in the private sector. Improving infrastructure is also another way the government aims to stimulate growth in the private sector.

Saudi Arabia is planning to transform into a knowledge-based economy by introducing new policies relating to ICT. By human resource development, the government provides basic ICT training for women and adults. A challenge that Saudi Arabia faces is the number of women that are unemployed; therefore a policy to in providing ICT training will increase employment opportunities for women (Nurunnabi, 2017). Another policy introduced by the Saudi government 
are subsidies for the creators of local digital content to stimulate growth in this sector. The policy to provide funding for the use of ICT tools in education such as tablet PCs or online learning programs is a policy that will improve access to knowledge. The introduction of computer applications to manage various operation systems in the business sector is also another step in transforming the nation into a knowledge base economy.

\section{Conclusion}

Evidently, the adoption of a knowledge-based economy by nations is important as it allows for sustainable economic growth through diversification. A knowledge-based economy is one that relies more on its intellectual capabilities rather than natural resources or physical inputs. As such, knowledge-based economies are less susceptible to internal and external threats such as changes in prices as they have higher levels of adaptability and flexibility. The main features or attributes of a knowledge base economy are increased investment in human capital, education and the access to funding for technological companies. Another feature is the high level of demand for high skilled workers. Saudi Arabia has been preparing to transform into a knowledge-based economy by introducing Vision 2030 and the National Transformation Program 2020 plans. Also, the government has also introduced new policies aimed at promoting ICT initiatives such as access to funding for startups and the use of ICT tools in education. 


\section{Reference}

1. Ejdys, J., Ustinovičius, L., \& Stankevičienè, J. (2015). Innovative application of contemporary management methods in a knowledge-based economy-interdisciplinarity in science. Journal of Business Economics and Management, 16(1), 261-274.

2. Fang, L. H., Lerner, J., \& Wu, C. (2017). Intellectual property rights protection, ownership, and innovation: Evidence from China. The Review of Financial Studies, 30(7), 2446-2477.

3. Hadad, S. (2017). Knowledge economy: Characteristics and dimensions. Management Dynamics in the Knowledge Economy, 5(2), 203-225.

4. McCarthy, M. (2017). Venezuela's Crisis: Beyond Economic Explanations. Georgetown Journal of International Affairs, 18(2), 129-136.

5. Mitchell, B., \& Alfuraih, A. (2018). The Kingdom of Saudi Arabia: Achieving the Aspirations of the National Transformation Program 2020 and Saudi Vision 2030 Through Education. Journal of Education and Development, 2(3), 36.

6. Nurunnabi, M. (2017). Transformation from an oil-based economy to a knowledge-based economy in Saudi Arabia: the direction of Saudi vision 2030. Journal of the Knowledge Economy, 8(2), 536-564.

7. Pan, C.-I., Chang, T., \& Wolde-Rufael, Y. (2015). Military spending and economic growth in the Middle East countries: Bootstrap panel causality test. Defence and Peace Economics, 26(4), 443-456. 